\title{
PERSEPSI ANAK TENTANG RUANG BERMAIN RAMAH ANAK DI BANTARAN KALI BANGER KEL KEMIJEN
}

\author{
Mila Karmilah \\ Program Studi Perencanaan Wilayah dan Kota Universitas Islam Sultan Agung Semarang \\ Penulis Korespondensi e-mail: mila.k@unissula.ac.id
}

\begin{abstract}
ABSTRAK
The majority of the Indonesian population lives in Kampong in higher density, and one of them is living in the riverbank area. The characteristics of urban are having inadequate infrastructure conditions, lack of water supply, and lack of waste management. One of inadequate of infrastructure is playing facilities for children. This study will look at children's perceptions regarding the location that responsive to children's needs. The location of this study is the Kali Banger in the Kemijen sub-district. In Kemijen Sub district, there are $11 \mathrm{RW}$ and eight of them are directly facing Kali Banger. This study uses a mixed approach (quantitative and qualitative) in extracting data. The study showed that children's perceptions of rivers are the convenient locations for playing, so they want the river to be clean. Children also have a good understanding of environmental hygiene, especially at Kali Banger. The locations that are often used to play are pump points, pump house roofs, playgrounds that located on $R W$, roads and railroad tracks. The choices of location for children's play was triggered by the condition of their houses, so they chosen to play in outdoor location until afternoon. This finding can be a reference for the development of Indonesian urban kampung that are more conducived to children, especially kampung on the riverbank. After mapping the existing location and location that children sugesting that responsive child's needs and types of games, it was seen that the most desirable locations for playing locations were p33laygrounds (54.5\%), then soccer fields $(22.1 \%)$ and the rest are varied, while the types of games that were desired were swing (39\%) and see saw of $(18.2 \%)$
\end{abstract}

Key Words: Perception, Play Ground, Children and Responsive Children

\begin{abstract}
ABSTRAK
Mayoritas penduduk kota Indonesia tinggal di kampung dengan tingkat kepadatan yang tinggi, salah satunya adalah keberadaan permukiman di kawasan bantaran sungai. Ciri kampung kota memiliki kondisi infrastruktur, yang belum memadai salah satunya adalah fasilitas bermain bagi Anak. Studi ini akan melihat persepsi anak terkait lokasi bermain yang ramah (responsif) dengan kebutuhan usia anak. Lokasi penelitian ini adalah kawasan bantaran Kali Banger yang terletak di Kelurahan Kemijen, dari 11 RW yang terdapat di kelurahan Kemijen terdapat 8 RW yang langsung berhadapan dengan kali Banger. Studi ini menggunakan pendekatan campuran (kuantitatif dan kualitatif) didalam penggalian data-data. Temuan studi memperlihatkan bahwa persepsi anak tentang sungai/kali adalah sebagai lokasi yang nyaman sebagai tempat bermain, sehingga mereka menginginkan kali dalam kondisi bersih. Anak-anak juga mempunyai pemahaman yang baik mengenai kebersihan lingkungan khususnya pada kali Banger. Lokasi yang sering digunakan untuk bermain adalah beberapa titik pompa, atap rumah pompa, taman yang berada di RW 8, jalan lingkungan dan rel KA. Pemilihan lokasi bermain anak ini dipicu oleh kondisi rumah mereka yang sempit, sehingga mereka memilih keluar rumah sepulang sekolah sampai sore hari. Temuan ini dapat menjadi acuan bagi pengembanmgan kampung kota Indonesia yang lebih kondusif untuk anak, khususnya kampung bantaran sungai. Setelah dilakukan pemetaan baik eksisting dan rencana lokasi dan jenis permainan maka terlihat bahwa lokasi yang paling banyak diminat sebagai lokasi bermain adalah taman bermain (54.5\%), kemudian lapangan sepakbola $(22,1 \%)$ dan sisanya bervariasi, sedangkan jenis permainan yang banyak diinginkan adalah ayunan (39\%) dan jungkat-jungkit sebesar (18,2\%).
\end{abstract}

Kata Kunci : Persepsi, ruang bermain, anak, ramah anak 


\section{PENDAHULUAN}

Aktifitas dan jumlah manusia yang terus meningkat dari tahun ke tahun, berimplikasi terhadap kebutuhan akan ruang untuk kawasan hunian maupun ruang kegiatan lain (sosial, budaya, dan ekonomi) terutama di kota-kota besar. Kota Semarang sebagai ibukota Provinsi Jawa Tengah telah lama menjadi tujuan migrasi bagi penduduk kota lain sebagai tempat mencari penghidupan baru. Arus migrasi yang tinggi di kota-kota besar berbanding lurus dengan okupansi lahan termasuk lahan yang berada di pinggiran sungai, rel kereta api, maupun tempat lain yang tidak dipersiapkan sebagai lahan permukiman formal.

Keterbatasan fasilitas umum yang berada di permukiman informal memaksa penduduk untuk lebih kreatif dalam memanfaatkan ruang sebagai salah satu langkah adaptasi mereka. Tidak terkecuali bagi anak-anak. Anak-anak yang secara alami membutuhkan ruang untuk bermain dan bersosialisasi, sebagai langkah adaptasi karena keterbatasan ruang bermain, mereka memilih lokasi-lokasi seadanya di bantaran sungai sebagai tempat bermainnya seperti yang terjadi di bantaran sungai Banger, Kelurahan Kemijen, Semarang.

Tantangan sekaligus permasalahan di perkotaan yaitu salah satunya tentang penataan kota yang harus memberikan kota yang ramah lingkungan dan tidak hanya dipenuhi dengan elemen solid atau bangunan-bangunan keras, melainkan dengan menyajikan kota dengan elemen-elemen void seperti ruang terbuka ataupun elemen alam. Selain membuat wajah kota menjadi nyaman dipandang, elemen kota memungkinkan warga di perkotaan memiliki persepsi dan apresiasi yang jauh lebih baik terhadap lingkungan (Christensen, 2003).

Warga perkotaan tidak hanya terdiri dari orang-orang dewasa saja, melainkan anakanak juga. Anak-anak dapat dikatakan bagian penting warga kota yang mempunyai hak hidup, berkembang, dan bermain. Suatu kota yang tidak menyediakan ruang yang diperuntukkan untuk anak-anak termasuk kota yang tidak mempunyai masa depan yang baik (Charnstra, 1997). Penyediaan ruang bermain anak merupakan bagian penting dalam perencanaan kota. Ruang bermain anak hendaknya mampu memfasilitasi perkembangan kognisi anak dalam hal kota maupun lingkungan secara luas (Chawla, 2002) dalam B. Setiawan, (2006)

Hurlock (1980) berpendapat bahwa masa kanak-kanak merupakan masa awal dimulainya interkasi dengan lingkungan baik secara fisik, psikologis, maupun sosial. Pada 
masa kanak-kanak juga mulai terbentuk karakter, sifat, dan potensi manusia di masa depannya. Lingkungan bermain yang nyaman, aman, sehat dan mempunyai elemen alami mampu menciptakan kognisi yang lebih baik di masa depan.

Artikel ini ditulis dalam rangka memetakan kebutuhan ruang bermain anak di bantaran sungai melalui kegiatan edukasi, yaitu Sekolah Sungai, yang bertujuan untuk mengidentifikasi dan memberikan edukasi 'lingkungan hidup' bagi masyarakat bantaran sungai Banger utamanya anak-anak yang merupakan generasi penerus. Sehingga pembentukan sekolah sungai menjadi suatu yang penting untuk dilakukan utamanya di kawasan sepanjang Kali Banger. Kawasan Kemijen terdiri dari 11 RW dengan jumlah penduduk 8300 jiwa Berikut adalah lokasi kawasan yang penelitian.

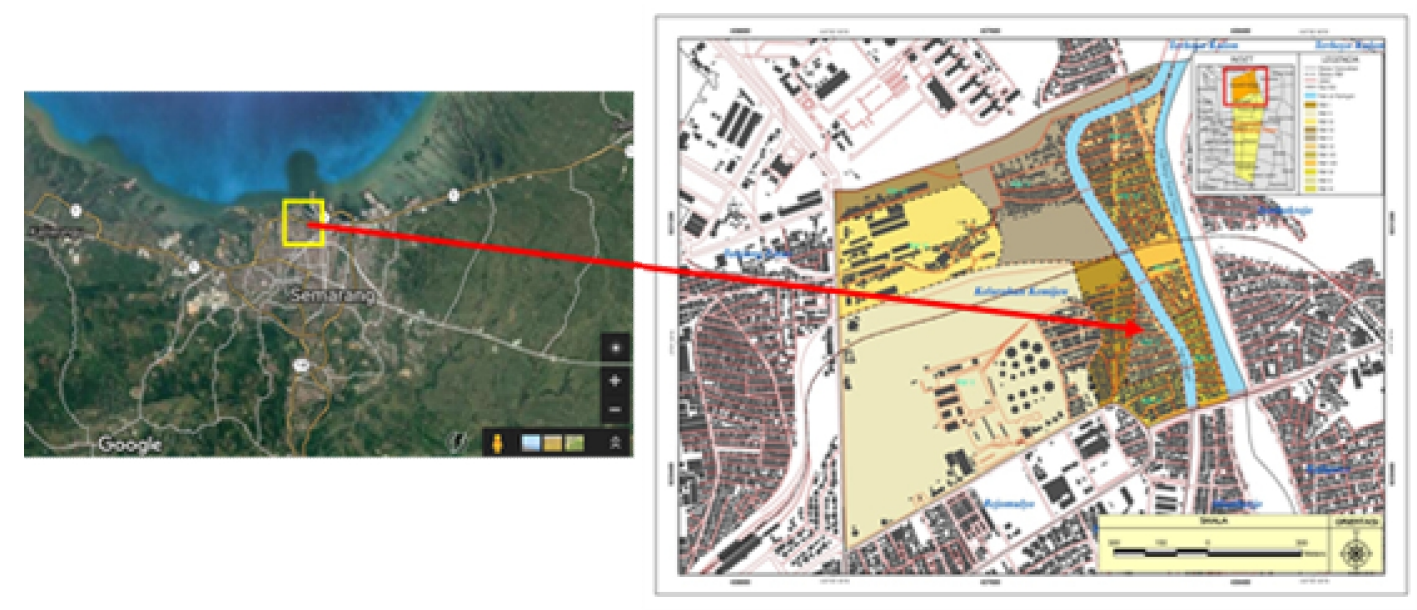

Gambar 1. Lokasi studi di kelurahan Kemijen Semarang Timur Sumber : GoogleEarth dan Hasil Olahan Peneliti, 2018

Terdapat banyak permasalahan mengenai lingkungan hidup di sungai Banger, seperti misalnya banjir dan rob. Saat ini, sungai Banger mengalami proses eutrophication (eutrofikasi), pendangkalan, sampah dan bau yang berasal dari tubuh sungai (gambar 1). Gambar 1 menunjukan permukaan air sungai yang ditumbuhi eceng gondok, disebabkan karena tingkat pendangkalan yang tinggi dan banyaknya nutrien yang masuk ke air sehingga eceng gondok tersebut menghambat aliran air sungai 
Jurnal Planologi Vol. 16, No. 1, April 2019

Available : http://jurnal.unissula.ac.id/index.php/psa
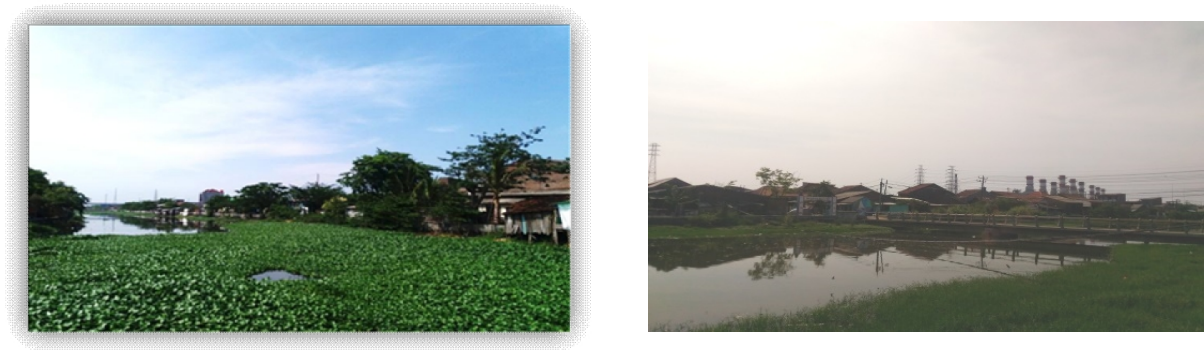

Gambar 2. Eutrofikasi, pendangkalan, sampah, dan polusi bau di tubuh sungai Banger Kemijen, Semarang sumber : Dokumentasi Pribadi, 2017.

\section{Ruang bermain yang beresiko}

Kelurahan Kemijen juga menghadapi permasalahan sosial selayaknya image yang melekat pada kawasan permukiman di bantaran sungai, seperti misalnya kemiskinan, kumuh, kriminalitas tinggi, dan keterbatasan ruang bermain. Dalam memanfaatkan ruang terbuka sebagai lokasi bermain, banyak dari mereka yang memilih tempat-tempat beresiko seperti atap bangunan rumah pompa, jembatan, bahkan tepi rel kereta api.

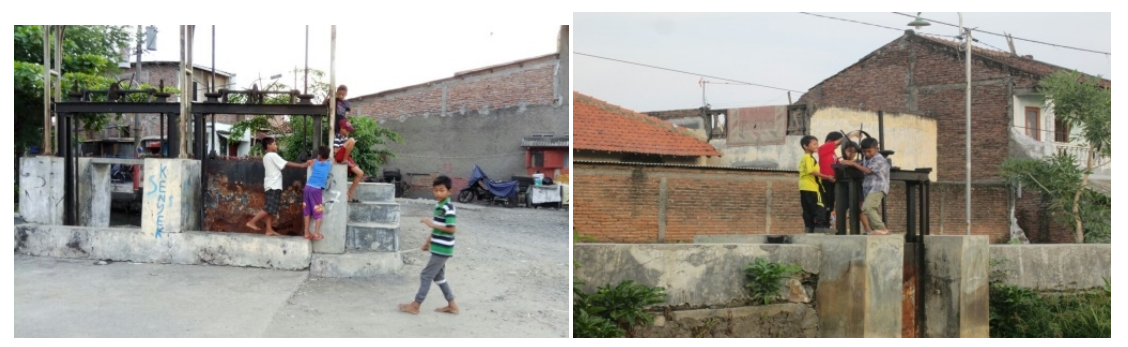

Gambar 3. Anak-anak bermain di pintu air karena keterbatasan ruang terbuka sebagai tempat bermain dan bersosialisasi

Sumber : Dokumentasi Pribadi, 2017
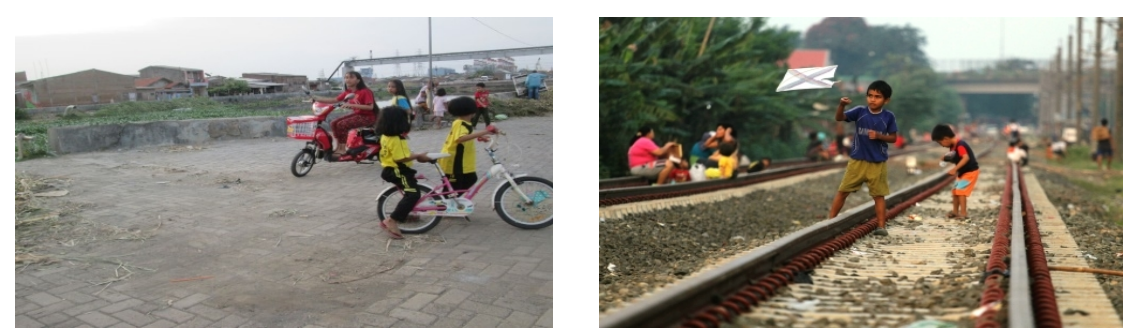

Gambar 4 Anak-anak bermain di sepanjang jalan di tepi sungai Sumber: dokumentasi pribadi, 2017. 
Jurnal Planologi Vol. 16, No. 1, April 2019

Available : http://jurnal.unissula.ac.id/index.php/psa

\section{METODOLOGI}

\subsection{Kajian Pustaka}

\subsubsection{Aspek sosial dalam proses perencanaan wilayah}

Telah banyak penelitian yang menulis tentang penilaian aspek sosial dalam perencanaan wilayah. Aspek sosial lebih menekankan pada strategi implementasi dari suatu kegiatan dan pentingnya peran pemerintah sebagai pengontrol dan pelaksana kebijakan atau undang-undang perencanaan (Knight et al, 2006). Terdapat dua hasil penting di dalam pembangunan terkait aspek sosial, (1) adanya kecocokan antara data keruangan dan sumberdaya yang ada, (2) angka keberhasilan pelaksanaan program akan lebih tinggi karena adanya proses identifikasi langsung ke objek yang membutuhkan (NC Ban et al, 2013). Saat ini, penilaian dari aspek sosial merupakan komponen penting dalam sebuah proses perencanaan karena mampu menggambarkan secara nyata kondisi sosial, budaya, ekonomi, dan politik di tempat tersebut (Knight et al. 2006; Conservation Measures Partnership 2007; Cowling and Wilhelm-Rechman, 2007).

\subsubsection{Kajian Perilaku Anak}

Penilaian tentang aspek sosial menitikberatkan pada sumberdaya lokal yang bertujuan untuk membentuk rasa memiliki dan kerjasama antara masyarakat dan pemerintah dalam setiap implementasi kegiatan. Kegiatan tersebut bisa merupakan kegiatan yang diinisiasi oleh masyarakat itu sendiri ataupun kegiatan strategis pemerintah daerah (Cowling and Wilhelm-Rechman, 2007).

Bermain merupakan kegiatan yang hampir selalu dilakukan oleh anak usia dini, karena bermain dapat memacu kreativitas anak dengan perilaku-perilaku yang dilakukan oleh anak-anak saat bermain yang sifatnya membangun. Kegiatan bermain yang dilakukan oleh anak-anak membutuhkan prasarana dan sarana diantaranya ruang bermain. Ruang bermain harus memiliki tempat yang nyaman, aman, baik dari segi fisik maupun psikis, karena ruang bermain berfungsi sebagai pusat aktivitas yang mampu memberikan stimulus anak sehingga anak bisa mengembangkan kreativitasnya.

Bronfrenbrenner (dalam Sari, 2004), berpendapat bahwa lingkungan yang pertama kali membentuk perkembangan anak usia dini (pra sekolah) yaitu lingkungan rumah. Selain itu, lingkungan di luar rumah juga dapat mempengaruhi perkembangan anak usia dini. Lingkungan di luar rumah yang mampu mempengaruhi perkembangan anak usia dini yaitu dari lembaga pra sekolah (guru/pengasuh, program/aktivitas dan fisik yaitu elemen ruang, warna dan furniture). Sedangkan menurut Hurlock (1990) dalam (Deetje, 1999), 
faktor eksternal (lingkungan fisik) yang dapat mempengaruhi perkembangan anak yaitu sarana dan prasarana bermain yang mampu merangsang dan menciptakan eksperimentasi dan eksplorasi. Ruang bermain juga mempunyai fungsi merangsang psikologis anak dan memotivasi anak untuk bermain sambil belajar sesuai dengan perkembangannya.

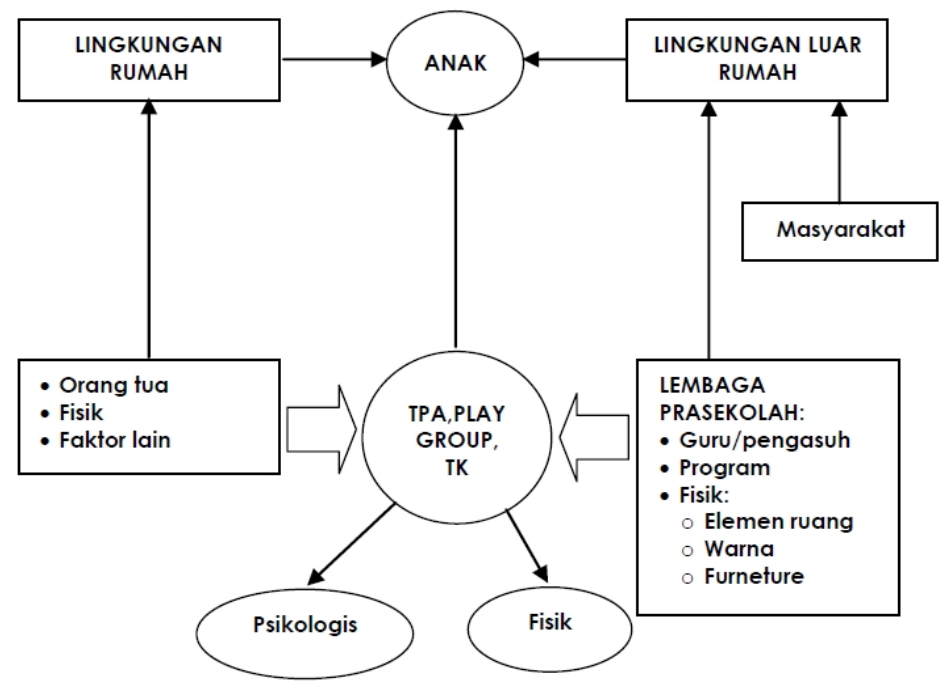

Gambar 5. Bagan Lingkungan Yang Mempengaruhi Perkembangan Anak Sumber : Bronfrenbrenner (dalam Sari, 2004)

Hohmann et.al. (1979) berpendapat bahwa permulaan perkembangan kognisi anak yaitu membenahi dan melengkapi ruang bermain. Anak-anak memerlukan suatu tempat atau ruang yang mampu digunakan sebagai tempat untuk berpindah, bergerak, berinteraksi dengan teman serta untuk memajang hasil karya yang telah dihasilkan. Pembagian area kerja dalam pembahasan ruang ini adalah area rumah; area seni; area balok/konstruksi; area tenang yang biasa digunakan untuk membaca, melukis dan sebagainya; dan pusat area yang digunakan untuk kegiatan bersama. Syarat-syarat ruang yang dikemukakan oleh Hohmann diantara space atau ruang yang memenuhi standar (menurut penelitian Legendre, space bermain anak adalah $\left.54 s q f t\left(5 \mathrm{~m}^{2}\right)\right)$; tembok dilapisi dengan papan bulletin dengan tinggi $4 \frac{1}{2}$ feet dengan fungsi yang dapat digunakan sebagai tempat pajangan karya anak, lantai selain area seni hendaknya ditutupi dengan karpet, kamar mandi yang terhubung dengan ruang bermain, peletakan stop kontak harus jauh dari jangkauan anak-anak, arah pintu terbuka mengarah ke luar, peletakan mainan hendaknya diletakkan di tempat yang mudah dijangkau oleh anak-anak.

Menurut Hurlock (1980), siklus terpenting pada kehidupan manusia terjadi pada masa anak usia dini. Dia juga mengkategorikan range masa anak usia dini yaitu range 
usia 0-13 tahun bagi wanita dan 0-14 tahun bagi laki-laki. Sedangkan tahap pada masa anak usia dini terdiri dari beberapa tahap dengan target dan pencapaian perkembangan secara maksimal. Piaget dalam Bechtel (1987), melakukan penelitian yang isinya mengenai pemahaman tentang keterkaitan perilaku anak dengan lingkungan fisik. Piaget menyatakan bahwa presepsi serta kognisi terhadap ruang tidak sama sesuai dengan umur anak. Perkembangan kognisi ruang berdasarkan umur dibagi menjadi 4 periode, diantaranya:

1. Periode sensorimotor (bayi, O-2 tahun)

2. Periode preoperasional (balita, 2-6 tahun)

3. Periode operasional konkret (usia sekolah atau middle childhood, 6 -12 tahun). Pada periode ini anak-anak mulai masuk ke dalam dunia baru serta pengalaman baru dimana anak sudah mulai masuk tingkatan sekolah dasar dan pola hidup anak mulai berubah. Menurut para ahli psikologi, usia pada periode ini biasa disebut dengan usia usia berkelompok, usia kreatif dan usia bermain.

4. Periode operasional formal (usia remaja dan dewasa, 13 tahun ke atas).

Selain itu, Hurlock (1980) berpendapat bahwa terdapat hal-hal yang mampu mempengaruhi kegiatan bermain anak di akhir masa kanak-kanak, dianataranya sebagai berikut:

1. Keadaan sosial anak dengan kawan-kawannya;

2. Tingkat kesadaran anak terhadap perbedaan gender.

3. Kondisi lingkungan;

4. Akivitas lain yang mengurangi kegiatan bermain anak.

Perbedaan jenis kelamin juga mampu mempengaruhi sikap anak dalam bermain seperti dalam hal penggunaan ruang, waktu, lokasi, dan jangkauan area bermain. Perbedaan jenis kelamin tidak terlalu terasa pada saat anak usia dini, namun hal ini berbeda saat anak sudah masuk ke tingkat sekolah dasar, anak-anak sudah mampu memahami perbedaan jenis kelamin dan kecenderungan dalam bermain. Berdasarkan beberapa masalah diatas maka disusunlah beberapa kegiatan yang digunakan untuk mendukung keberadaan sekolah sungai.

\subsection{Metode Penelitian}

Metode yang digunakan pada penelitian ini adalah metodologi kualitatif dengan pendekatan naturalistik, studi kasus Kawasan Kemijen yang berada di sepanjang Kali Banger. Penelitian ini menggunakan pendekatan naturalistik dengan harapan dapat 
dibangun pemahaman dan perumusan hipotesis baru terhadap tema penelitian. Hal ini sesuai dengan yang disampaikan Bechtel (1987), penelitian tentang perilaku anak dalam setting lingkungan tertentu dapat menggunakan berbagai teknik diantaranya: observasi, wawancara, pemetaan serta teknik-teknik lain termasuk yang menuntut sedikit keahlian verbal dan grafis anak.

\section{HASIL DAN PEMBAHASAN}

Berdasarkan hasil survey dilapangan dan focus group discussion (FGD) bersama anak-anak dari seluruh RW di Kelurahan Kemijen, menghasilkan peta lokasi bermain anak dan aktivitas bermain anak. Setiap anak dari masing-masing RW memetakan lokasi bermain dan apa yang mereka lakukan dengan cara menancapkan "bendera aspirasi" di lokasi yang diinginkan. Selama ini anak-anak di Kelurahan Kemijen bermain di sekitar rumah pompa yang terletak di RW 01, di jalan depan rumah, dan di salah satu rumah anak di RW 05, 08, dan 06.

Tabel 1. Setting Lingkungan Bermain Anak

\begin{tabular}{|l|l|l|l|}
\hline No & Jenis Permainan & \multicolumn{1}{c|}{ Deskripsi } \\
\hline 1 & Berenang & $\begin{array}{l}\text { Dilakukan secara berkelompok } \\
2-6 \text { orang dan cenderung } \\
\text { dilakukan oleh anak laki-laki }\end{array}$ \\
\hline 2 & Bermain Layangan & $\begin{array}{l}\text { Dilakukan secara berkelompok } \\
\text { 2-6 orang dan cenderung } \\
\text { dilakukan oleh anak laki-laki, } \\
\text { untuk yang bermain layangan } \\
\text { di atas rumah pompa biasanya } \\
\text { anak laki-laki }\end{array}$ \\
\hline
\end{tabular}




\begin{tabular}{|c|c|c|c|}
\hline No & Jenis Permainan & Deskripsi & Setting Lingkungan \\
\hline 3 & $\begin{array}{l}\text { Memancing/Menjaring } \\
\text { ikan di tambak dan } \\
\text { sungai }\end{array}$ & $\begin{array}{l}\text { Dilakukan secara berkelompok } \\
2-4 \text { orang oleh anak laki-laki } \\
\text { dan perempuan }\end{array}$ & $\begin{array}{l}\text { Seting sungai untuk mencari } \\
\text { karmancing/menjala }\end{array}$ \\
\hline 4 & Bermain sepeda & $\begin{array}{l}\text { Dilakukan oleh anak laki-laki } \\
\text { dan perempuan }\end{array}$ & \\
\hline \multirow[t]{2}{*}{5} & \multirow[t]{2}{*}{$\begin{array}{lr}\text { Bermain } & \text { sepeda, } \\
\text { layangan, } & \text { kejar- } \\
\text { kejaran, } & \text { ngobrol, } \\
\text { menerbangkan merpati }\end{array}$} & \multirow[t]{2}{*}{$\begin{array}{l}\text { Dilakukan secara berkelompok } \\
2-4 \text { orang }\end{array}$} & \\
\hline & & & $\square$ \\
\hline 6 & $\begin{array}{l}\text { Melemparkan gigi ruji } \\
\text { sepeda ke bantalan rel } \\
\text { kereta api }\end{array}$ & $\begin{array}{l}\text { Dilakukan secara berkelompok } \\
2-4 \text { orang }\end{array}$ & Di bantaran rel KA \\
\hline 7 & $\begin{array}{l}\begin{array}{l}\text { Bermain } \\
\text { engklek, } \\
\text { boneka }\end{array} \\
\text { boneka- }\end{array}$ & $\begin{array}{l}\text { Dilakukan oleh anak } \\
\text { perempuan } \\
\text { berkelompok }\end{array}$ & $\begin{array}{l}\text { Rumah teman } \\
\text { bantaran }\end{array}$ \\
\hline
\end{tabular}

Sumber: Observasi Lapangan Dan Wawancara Dengan Anak, 2018

Berdasarkan hasil survey yang ada, maka dapat diketahui bahwa anak-anak mayoritas bermain di sepanjang sungai dan rel, lokasi yang tidak seharusnya sebagai wadah bermain karena berbahaya. Anak-anak yang bermain di sepanjang sungai dan rel dapat mengakibatkan hal-hal yang tidak diinginkan seperti kejadian anak tenggelam di sungai dan kecelakaan di rel kereta api.

Dengan metode FGD bersama anak-anak, mayoritas aspirasi anak-anak mengingkan taman bermain menjadi salah satu fasilitas yang ada dipermukiman mereka karena di sekitar permukiman tidak ada taman bermain dan mengakibatkan anak-anak bermain di tempat-tempat berbahaya seperti bantaran sungai dan rel kereta api. Selain taman, fasilitas yang diinginkan oleh anak-anak adalah lapangan bola, badminton, taman pintar, perpustakaan, voli dan kebun binatang yang dapat digunakan sebagai tempat 
bermain sekaligus tempat berinteraksi anak-anak. Berikut merupakan tabel aspirasi anakanak dan jumlah pemilih:

Tabel 2 Aspirasi anak-anak dan jumlah pemilih

\begin{tabular}{|r|l|r|}
\hline No & Aspirasi & Jumlah Pemilih \\
\hline 1 & Taman Bermain & 42 \\
\hline 2 & Lap Sepak Bola & 17 \\
\hline 3 & Badminton & 7 \\
\hline 4 & Taman Pintar & 4 \\
\hline 5 & Perpustakaan & 3 \\
\hline 6 & Voli & 3 \\
\hline 7 & Kebun Binatang & 1 \\
\hline \multicolumn{2}{|l|}{ Total } & 77 \\
\hline \multicolumn{2}{|l}{ Sumber: observasi lapangan, 2018 }
\end{tabular}

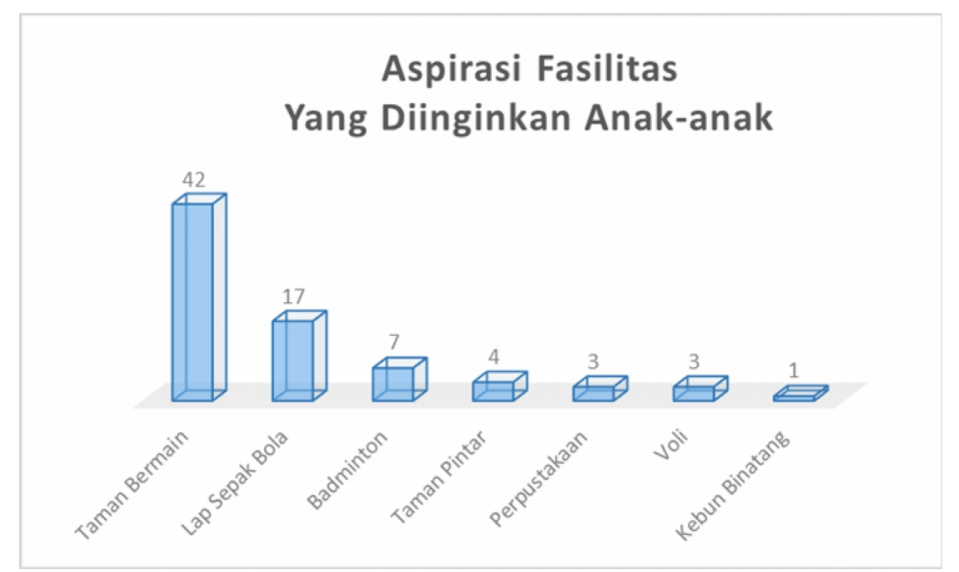

Gambar 6. Grafik Aspirasi Fasilitas yang diinginkan Anak-anak

Sarana dari fasilitas yang diinginkan anak-anak cenderung masih bersifat normal secara "culture" di Indonesia. Ayunan, jungkitan, bunga dan plorotan merupakan sarana yang paling diinginkan oleh anak-anak pinggir sungai Banger di Kelurahan Kemijen. Namun beberapa aspirasi juga menunjukkan aspek modernitas juga mulai ada di keinginan anak-anak pinggir sungai, seperti menginginkan fasilitas WiFi gratis. Aspirasi tentang sarana yang diinginkan oleh anak-anak di Kelurahan Kemijen muncul dari kebutuhan yang mereka butuhkan dan belum terpenuhi di permukiman mereka.

Tabel 3. Aspirasi Sarana dan jumlah pemilih

\begin{tabular}{|r|l|r|}
\hline No & Aspirasi & Jumlah Pemilih \\
\hline 1 & Ayunan & 18 \\
\hline 2 & Jungkitan & 14 \\
\hline
\end{tabular}




\begin{tabular}{|r|l|r|}
\hline \multicolumn{1}{|c|}{ No } & Aspirasi & Jumlah Pemilih \\
\hline 3 & Vegetasi & 12 \\
\hline 4 & Plosotan/Plorotan & 12 \\
\hline 5 & Kolam ikan & 4 \\
\hline 6 & Wahana Air & 5 \\
\hline 7 & Engkrak & 5 \\
\hline 8 & Wifi & 4 \\
\hline 9 & Wahan Pasir & 3 \\
\hline
\end{tabular}

Sumber: observasi lapangan, 2018

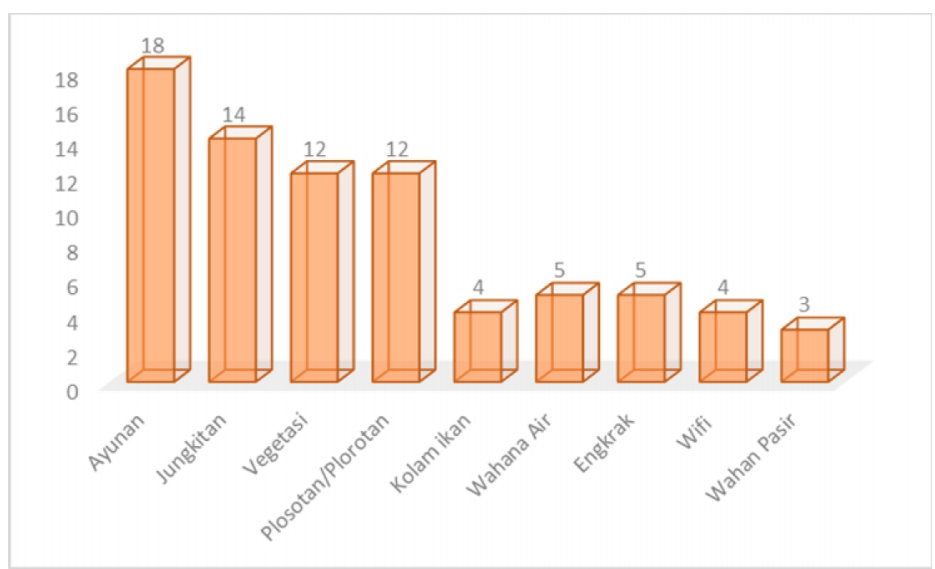

Gambar 7. Grafik Aspirasi Sarana

Berdasarkan kegiatan sosialisasi tentang kesiapsiagaan mitigasi bencana yang dilaksanakan di Kelurahan Kemijen dapat disimpulkan bahwa anak-anak di Kelurahan Kemijen telah cukup mengetahui tentang cara-cara hidup sehat dan cara-cara dalam mitigasi bencana. Sosialisasi dilakukan dengan cara penayangan film-film edukasi tentang mitigasi bencana dan bermain ular tangga yang disetiap angkanya terdapat edukasi tentang mitigasi bencana. Melalui kegiatan-kegiatan tersebut kita dapat memberikan ilmu-ilmu tentang mitigasi bencana kepada anak-anak di Kelurahan Kemijen. Selain itu, anak-anak di Kelurahan Kemijen telah faham tentang rambu-rambu terkait dengan bencana seperti tiik kumpul saat terjadi bencana dan jalur evakuasi. Rambu-rambu tersebut biasa mereka temui di rumah sakit, mall, hotel, dll. Anak-anak di Kelurahan Kemijen juga telah mengetahui macam-macam bencana seperti kebakaran, banjir, tsunami, gempa bumi, dll. Mereka juga mengetahui apa penyebab dan cara mencegah terjadinya bencana, seperti kebakaran yang disebabkan karena lupa mematikan kompor dan dapat diantisipasi dengan selalu mematikan kompor setelah memasak dan memriksa kembali apakah kompor telah dimatikan atau belum. Kegiatan tersebut dapat dilihat pada gambar di bawah ini. 


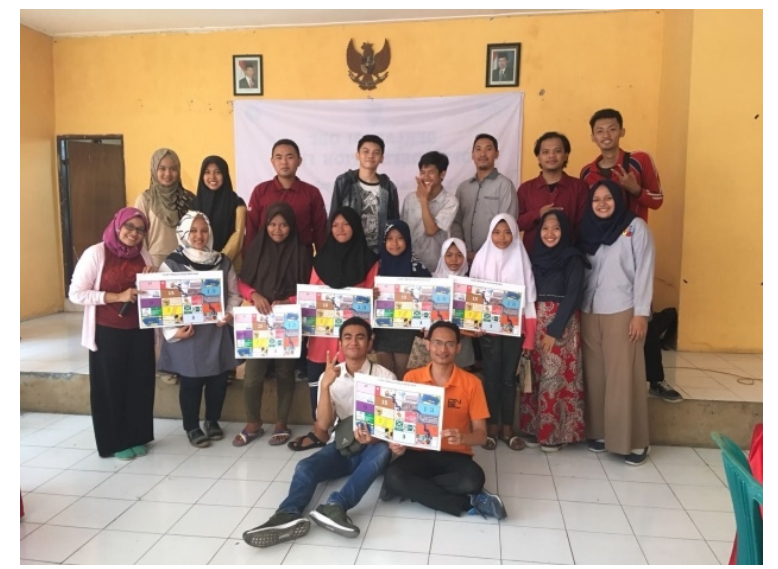

Gambar 8. Kegiatan Sosialisasi dan Kesiapsiagaan Mitiasi Bencana Sumber : Dokumentasi Pribadi, 2018

Pemetaan Aspirasi Anak "Ruang Bermain Anak di Kemijen Peta tersebut menunjukan blok-blok sebagai media untuk mempermudah anak-anak menentukan lokasi yang diinginkan. Wilayah Kemijen yang ada di sekitar Sungai Banger dibagi menjadi 8 Blok. Anak-anak pun menunjukan secara langsung lokasi mereka bermain dan lokasi yang diinginkan sebagai tempat bermain yang baru di tiap blok nya. Sebagian besar anak-anak kemijen menginginkan adanya taman bermain yang menyenangkan dengan berbagai permainan di dalamnya. Selain itu, ada juga beberapa kelompok menginginkan taman dengan akses free wifi. Ada juga kelompok yang menginginkan adanya taman mini zoo yang menyediakan binatang-binatang seperti kucing, kelinci, anjing dan anak-anak bisa berinteraksi langsung dengan hewan-hewan tersebut.

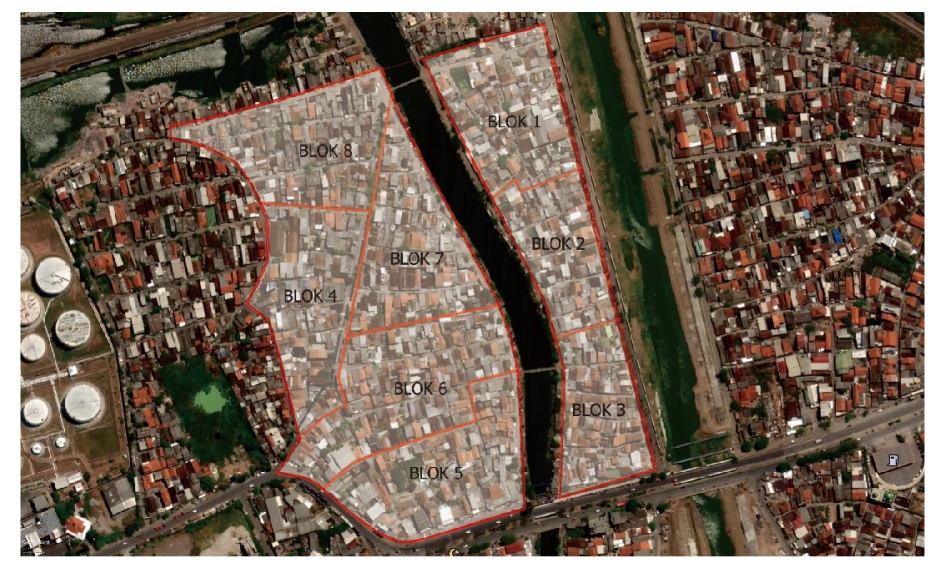

Gambar 9. Peta Pembagian Blok

Sumber : GoogleEarth dan Hasil Olahan, 2018 
Untuk lebih jelas dibawah akan dijelaskan lokasi dan keinginan dari tiap kelompok hasil diskusi tersebut. Di peta tersebut akan dijelaskan dimana lokasi dan bagaimana keinginannya.

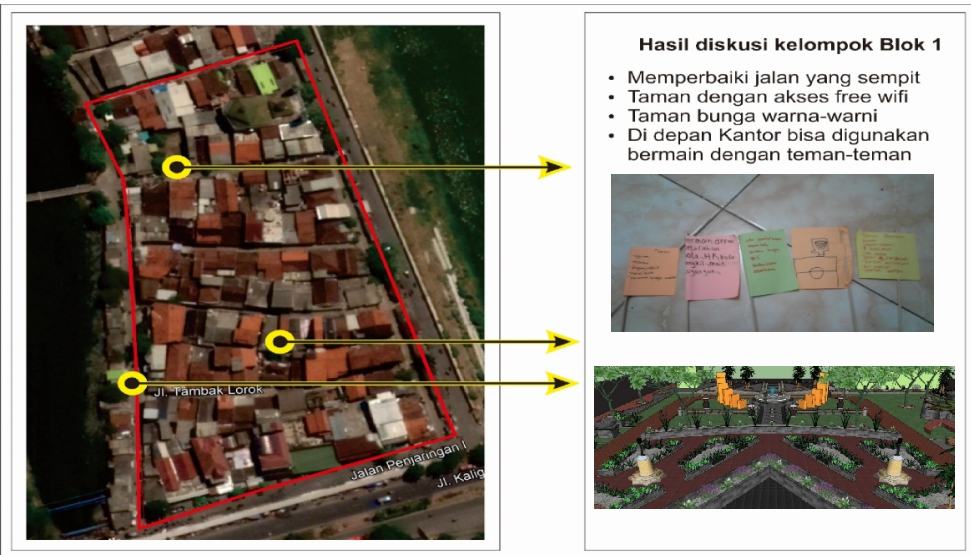

Gambar 10. Hasil Diskusi Kelompok Blok 1 Sumber : GoogleEarth dan FGD 2018

Hasil dari blok 1 disekitar RW IX anak-anak menginginkan taman dengan akses free wifi untuk menunjang belajar mereka. Selain itu, dibangunkan taman bunga warnawarni. Tempat yang ditunjukan yaitu bisa di depan Kantor Kelurahan Kemijen. Atau lahan tidak terpakai di antara rumah-rumah.

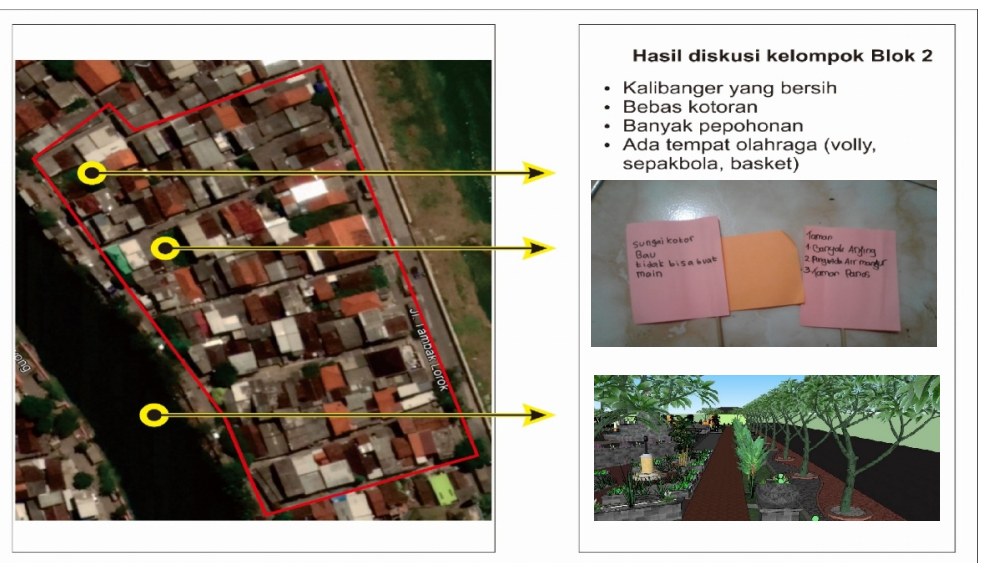

Gambar 11. Hasil Diskusi Kelompok Blok 2 Sumber : GoogleEarth dan FGD 2018

Dari blok 2 RW 8 anak-anak mendiskusikan dan menginginkan Sungai Banger yang bersih, karena kondisi sekarang masih penuh sampah dan menimbulkan bau yang tidak sedap. Selain itu, mengharapkan banyak pepohonan di sekitar sungai agar rindang dan teduh. Dan juga ada tempat olahraga seperti lapang sepakbola, volly, dan basket di lingkungan mereka. Untuk lokasi seperti yang ada pada Gambar 12. 


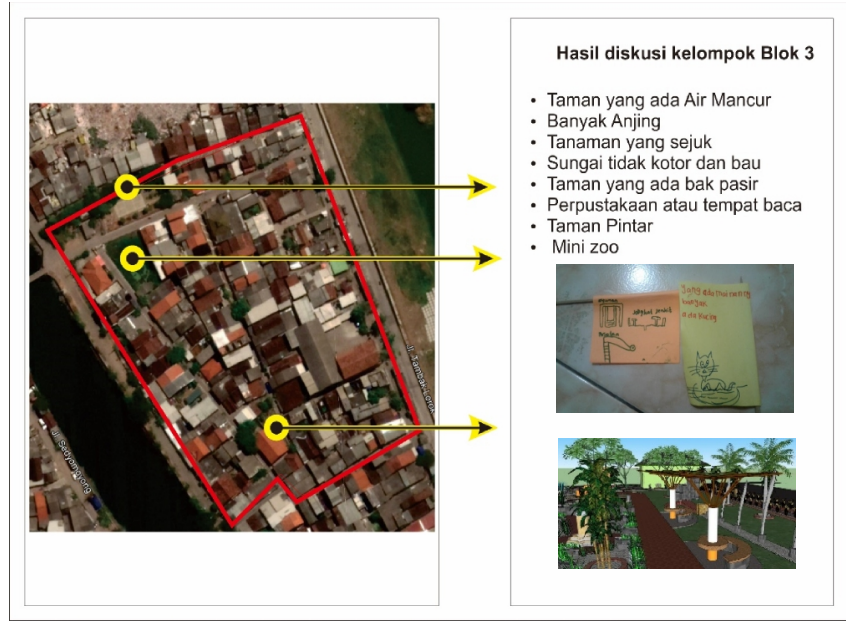

Gambar 12. Hasil Diskusi Kelompok Blok 3 Sumber : GoogleEarth dan FGD 2018

Diskusi dari blok 3 yaitu disekitar RW 6 dan 7 mengingkan adanya taman dengan air mancur, ada tanaman yang membuat sejuk. Selain itu, pembersihan sungai agar tidak bau dan kotor sehingga tidak mengganggu waktu main mereka. Ada juga yang menginginkan adanya perpustakaan atau taman baca. Selain mereka bermain, mereka juga bisa meluangkan waktu untuk baca-baca buku yang disediakan oleh taman baca tersebut. Ada juga yang menginginkan Mini Zoo yang terdapat hewan-hewan jinak dan mereka bisa berinteraksi langsung. Lokasi berada di taman yang sekarang sudah ada disana tetapi masih belum optimal dalam penggunaannya.

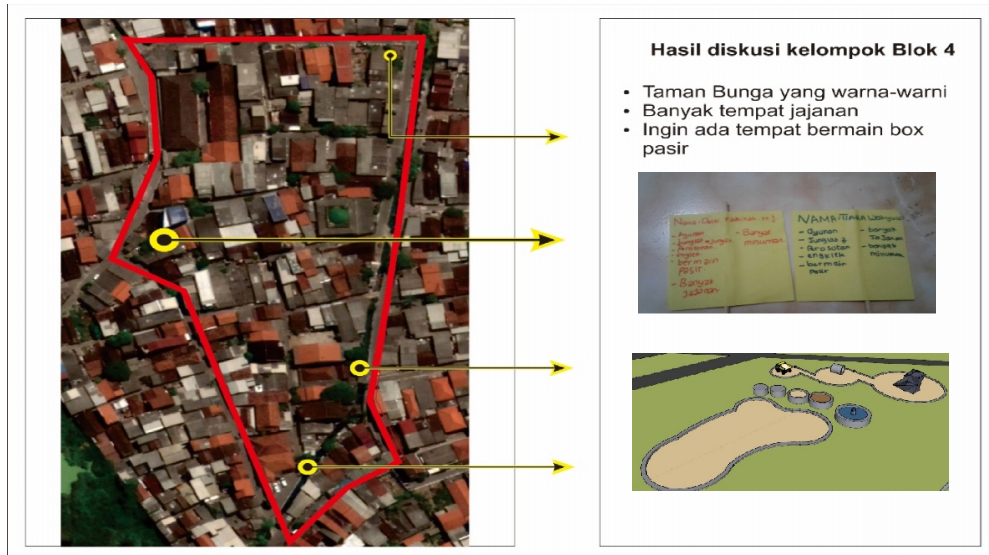

Gambar 14 Hasil Diskusi Kelompok Blok 4 Sumber : GoogleEarth dan FGD 2018

Dari diskusi anak-anak blok 4 didapatkan beberapa poin yaitu pertama adanya taman bunga warna-warni yang indah. Selain itu ditempat mereka nanti bermain ada banyak jajanan sehingga mereka tidak perlu jauh-jauh mencari jajan jika sedang bermain di 
taman tersebut. Yang ketiga yaitu mereka menginginkan ada tempat bermain berupa box pasir sehingga mereka bisa membuat kreasi dari pasir-pasir yang disediakan. Box pasir itu bisa digunakan anak-anak untuk membuat istana pasir ataupun rumah-rumahan dari pasir.

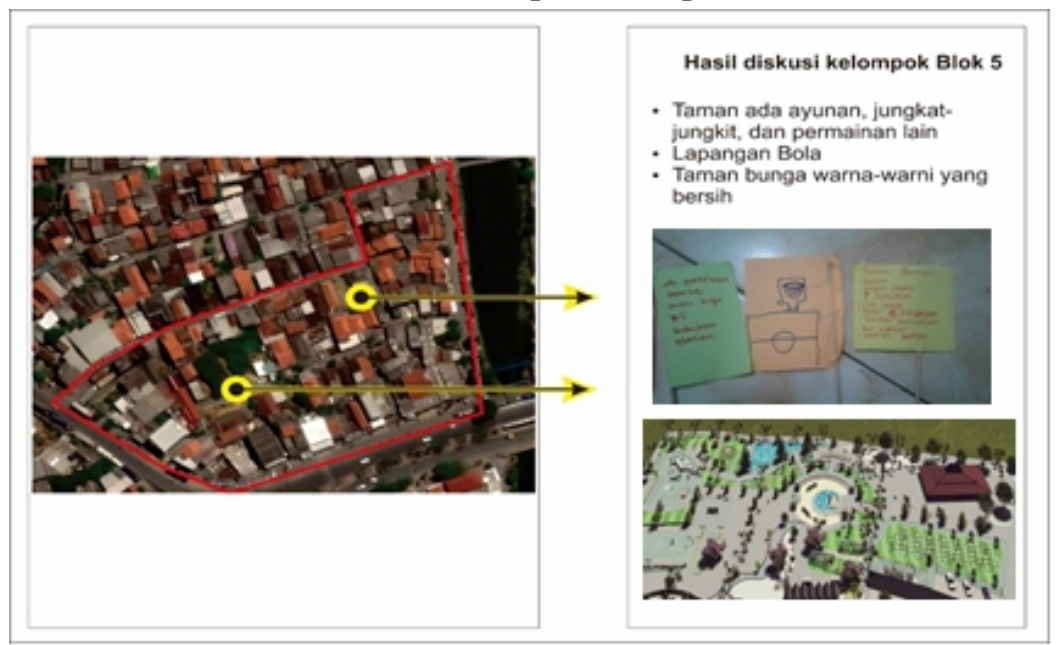

Gambar 15. Hasil Diskusi Kelompok Blok 5 Sumber : GoogleEarth dan FGD 2018

Hasil diskusi kelompok blok 5 didapatkan bahwa pertama mereka menginginkan taman yang ada atraksi permainan yang banyak seperti ayunan, jungkat-jungkit dan permainan lain yang bisa membuat anak-anak nyaman bermain ditempat tersebut. Selain itu, untuk anak laki-laki disediakan Lapangan bola yang luas dan bagus sehingga yang hobi bermain bola bisa main disana. Ada juga yang menginginkan tamannya ada bunga-bunga cantik berwarna-warni.

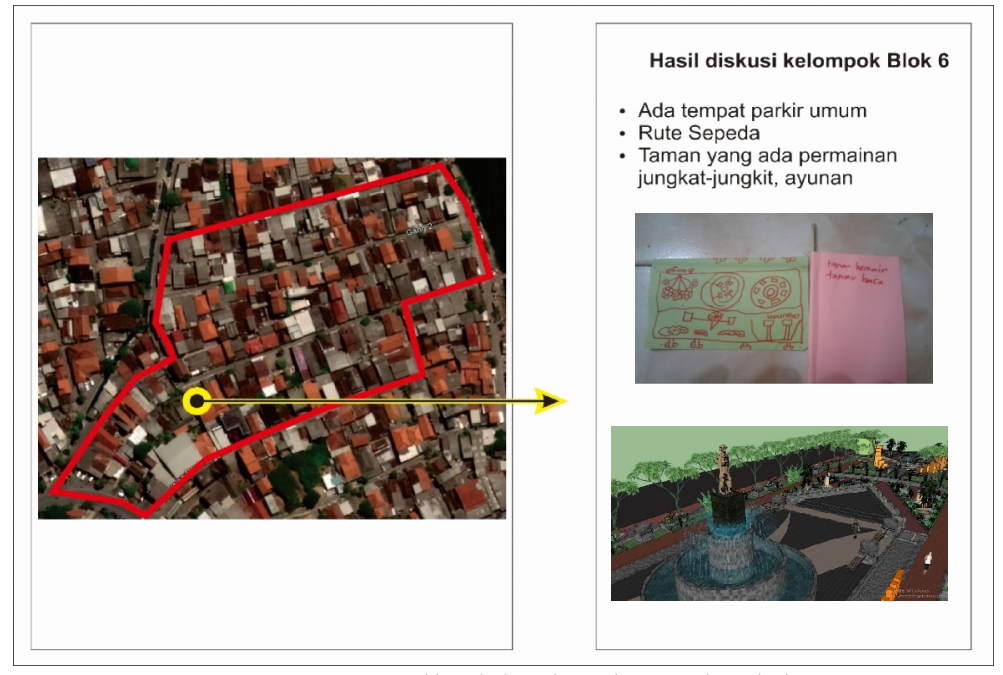

Gambar 16 Hasil Diskusi Kelompok Blok 6 Sumber : GoogleEarth dan FGD 2018 
Hasil dari diskusi Blok 6 didapatkan bahwa ingin ada tempat parkir umum yang luas, sepeda yang mereka bawa bisa diparkirkan di tempat yang aman. Ada juga rute sepeda yang baik sehingga anak-anak bisa bersepeda bersama ketika sore hari mengelilingi rute tersebut. Selain menyenangkan juga menyehatkan karena anak-anak bersepeda.

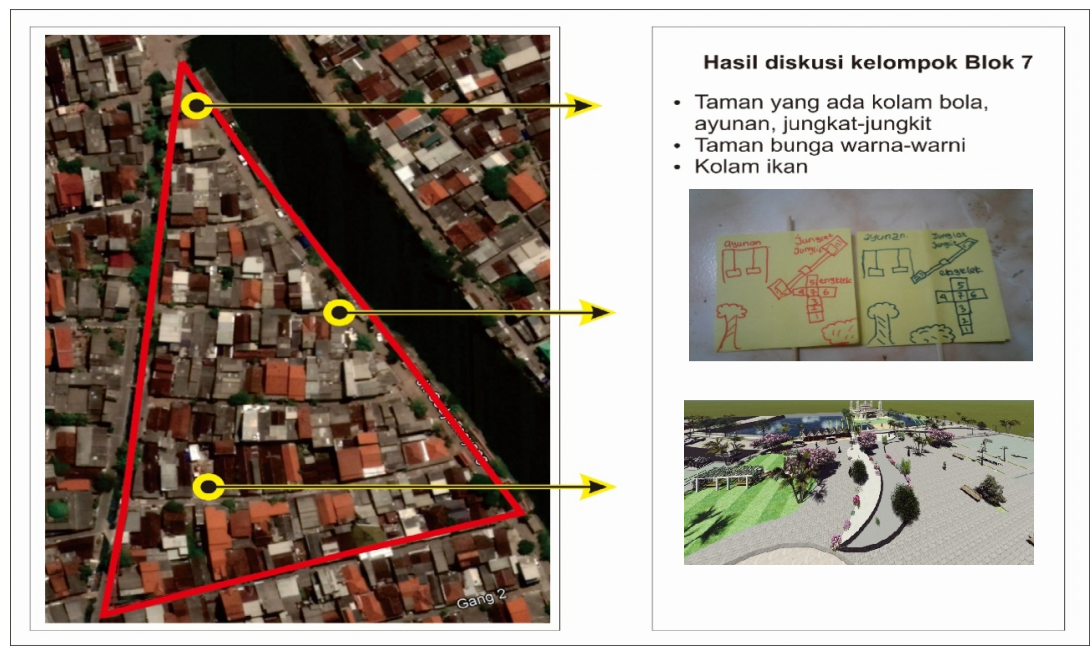

Gambar 17 Hasil Diskusi Kelompok Blok 7

Sumber : GoogleEarth dan FGD 2018

Di kelompok Blok 7 mendiskusikan dan menginginkan di sekitar rumah pompa yang sekarang bisa dijadikan tempat bermain yang menyenagkan dengan menambahkan tanaman-tanaman peneduh sehingga rindang dan sejuk. Selain itu ada taman dengan berbagai atraksi yang menyenangkan. Ada juga kolam mandi bola dan kolam ikan sehingga anak-anak bisa belajar membudidaya ikan sejak kecil.

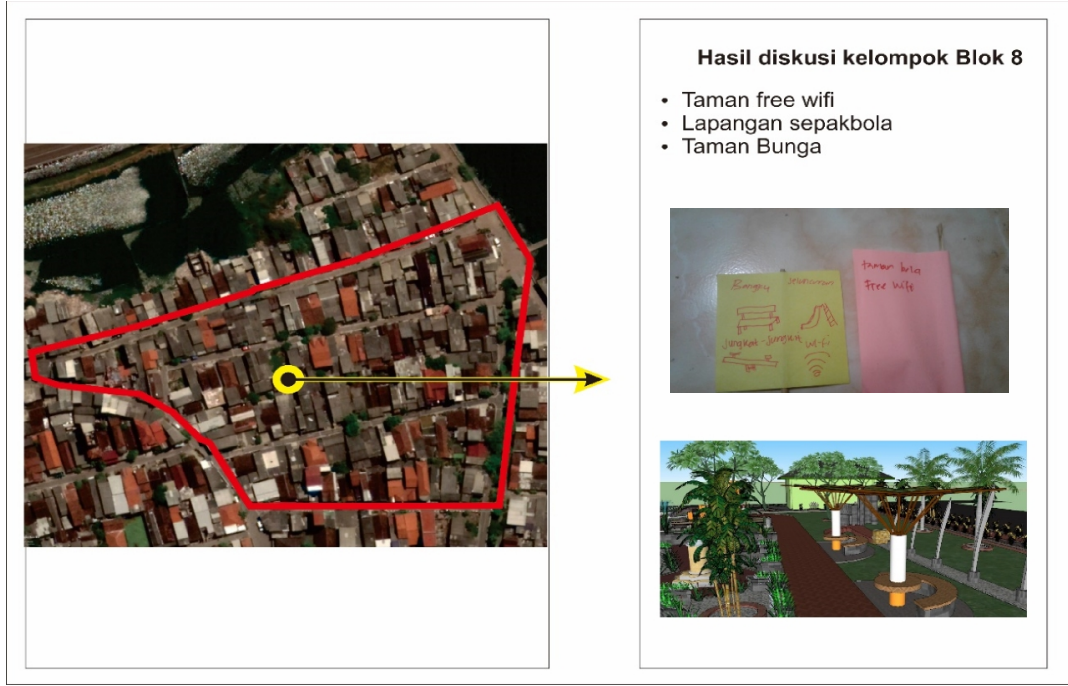

Gambar 18 Hasil Diskusi Kelompok Blok 8

Sumber : GoogleEarth dan FGD 2018 
Di kelompok blok 8 anak-anak menginginkan ada taman free wifi sehingga bisa browsing pelajaran-pelajaran mereka di sekolah. Ada juga lapangan sepakbola bagi anakanak yang suka bermain sepakbola. Selain ada lapangan sepak bola ada juga taman bunga yang cantik nan indah.

\section{KESIMPULAN DAN SARAN}

\subsection{Kesimpulan}

Penelitian ini menyimpulkan tiga hal penting. Pertama, bahwa anak-anak di area penelitian mempunyai persepsi yang positif terhadap sungai. Dari peta mental yang mereka buat, wawancara mendalam dan perilakunya, anak-anak mengetahui bahwa sungai merupakan bagian dari lingkungan perumahan mereka. Dalam konteks ini, anak-anak cenderung melihat sungai tidak sepenuhnya sebagai lingkungan alami, khususnya karena sungai yang sudah di talud. Mereka juga cukup memahami fungsi sungai dalam sistem lingkungan yang lebih luas. Singkatnya, anak-anak mempunyai persepsi lingkungan yang positif terhadap sungai. Persepsi yang positif ini menurut Heft (1999) krusial bagi pembentukan kepribadian anak di kemudian hari. Kedua, anak-anak di area penelitian juga mempunyai peluang untuk melakukan interaksi dengan seting sungai secara langsung. Dalam situasi keterbatasan lingkungan perumahan yang ada, mereka justru memanfaatkan sungai sebagai arena bermain yang menantang dan mereka senangi. Kondisi ini memungkinkan mereka melakukan proses pembentukan kognisi lingkungan yakni knowing, understanding, dan meaning (Rapoport, 1977). Dalam kerangka teori permainan untuk anak-anak sebagaimana dikatakan Chawla (2002), seting sungai justru memungkinkan mereka melakukan permainan yang positip dan mendidik. Ketiga, penataan ruang dan lingkungan, khususnya talud yang dibangun di sepanjang sungai, mengurangi peluang mereka untuk berinteraksi secara langsung dan optimal dengan sungai. Sungai yang kotor, dangkal, dan tidak ramah juga mengurangi pemahaman anak yang komprehensif terhadap sungai. Dengan kata lain, penataan ruang yang ada kurang optimal memfasilitasi pengembangan kognisi anak terhadap hakekat dan wujud sungai sebagai salah satu elemen lingkungan alami.

\subsection{Saran}

Penelitian ini menggunakan dua hal. Pertama, penataan ruang dan lingkungan perumahan harus memperhatikan kebutuhan anak untuk bermain dan mengembangkan kognisinya, khususnya terhadap alam dan lingkungan. Justru dalam seting perkotaan 
dimana ketersedian elemen alami yang terbatas, keberadaan sungai dan elemen alam lain harus dipertahankan dan dimanfaatkan untuk media pengembangan kognisi lingkungan anak terhadap alam dan lingkungan. Penataan lingkungan harus memungkinkan interaksi langsung anak dengan elemen alam yang ada, termasuk sungai. Dalam konteks ini pula, disarankan konservasi lingkungan sungai di wilayah perkotaan Semarang, yang tidak saja bermanfaat untuk menjaga keberadaan dan fungsi sungai, tetapi juga bermanfaat untuk tempat bermain dan pengembangan kognisi anak-anak yang tinggal di perkotaan. Kedua, disarankan penelitian komparasi di kampung-kampung lain, khususnya yang tidak berdekatan dengan lingkungan/elemen alami seperti sungai. Penelitian lanjutan ini untuk mengetahui apakah terdapat perbedaan persepsi dan kognisi anak yang tidak tinggal berdekatan dengan sungai. Penelitian lanjutan juga dapat dilakukan terhadap lingkunganlingkungan perumahan non-kampung atau yang lebih mapan, baik yang dekat dengan elemen alam maupun tidak. Penelitian-penelitian sejenis ini akan melengkapi pengetahuan dan pemahaman kita tentang persepsi dan perilaku anak-anak terhadap lingkungannya.

\section{DAFTAR PUSTAKA}

Setiawan. B, (2006). "Ruang Bermain untuk Anak di Kampung Kota: Studi Persepsi, Lingkungan, Seting dan Perilaku Anak di Kampung Code Utara Yogyakarta" Jurnal Manusia dan Lingkungan. 13 (2) 60-70.

Cowling, R.M., Wilhelm-Rechman, A., (2007), "Social assessment as a key to conservation success". Oryx. 41, 135-136.

Deetje, J.S., (1999), Kemampuan Berpikir Kreatif Dikaitkan Dengan Perilaku Otonomi, Suasana Interaksi Dalam Keluarga dan Proses Belajar Mengajar Siswa STM di Sulawesi Utara, Thesis S2 Program Psikologi Pendidikan dan Psikometri Fakultas Psikologi UGM Yogyakarta.

Hohmann, et,al., (1979), Young Children in Action (A manual for preschool educators), High/Scope Educational Research Foundation Ypsilanti, Michigan.

Hurlock, E., (1980) “Psikologi P erkembangan”. Penerbit Erlangga. Jakarta

https://www.bnpb.go.id/home/detail/3039/Gerakan-Sekolah-Sungai-Untuk-Pengurangan$\underline{\text { Resiko-Bencana }}$

http://pci.dynamicgovernance.id/our-program/sekolah-sungai/ http://article.sciencepublishinggroup.com/html/10.11648.j.aff.s.2015040401.15.html 
Jurnal Planologi Vol. 16, No. 1, April 2019

Available : http://jurnal.unissula.ac.id/index.php/psa

Knight, A. T., et al. (2006). "Designing systematic area-selection studies that promote effective implementation: best practice from South Africa", Conservation Biology $.20 .739-750$

NC Ban et al, (2013), “ A social-ecological approach to conservation planning: Embedding social considerations" Frontiers in Ecology and the Environment. 11 (4)

Sari S.M, (2004), "Peran Warna Interior terhadapPerkembangan dan Pendidikan Anak di Taman Kanak-Kanak” Jurnal Dimensi Interior. 2 (1) 22-36 